\title{
Gamma-Amino Butyric Acid Immunoreactivity in the Testis Tissue of Wistar and Genetic Absence Epilepsy Rats
}

\author{
Inmunorreactividad del Ácido Gamma-Amino Butírico en el Tejido \\ Testicular de Ratas Wistar con Epilepsia de Ausencia Genética
}

Duygu Gürsoy Gürgen ${ }^{1,2,3}$; Özlem Tugçe Çilingir Kaya ${ }^{1}$ \& Serap Sirvanci ${ }^{1}$

GÜRGEN, D. G.; ÇILINGIR, Ö. T. \& SIRVANCI, S. Gamma-amino butyric acid immunoreactivity in the testis tissue of Wistar and genetic absence epilepsy rats. Int. J. Morphol. 39(6):1709-1718, 2021.

SUMMARY: Studies have shown the adverse effects of epileptic seizures on reproductive health. The aim of the present study was to investigate morphological changes, apoptosis and GABA localization in the testis tissue of genetic absence epilepsy rats. Testis tissues of GAERS and Wistar rats were processed for paraffin embedding and electron microscopy. Sections were stained with hematoxylin and eosin, Masson's trichrome and periodic acid-Schiff reaction. GABA immunohistochemistry was applied for determining the alterations in GABA levels. GABA immunoreactivity was observed in the seminiferous tubules and interstitial areas of both GAERS and Wistar rats. GABA immunoreactivity was found to be decreased in GAERS compared to Wistar group. Electron microscopic observations showed that GABA was present in manchette microtubules, sperm tail and neck at different phases of spermiogenesis. Qualitative observations revealed that testis tissues of GAERS showed reduced sperm in the seminiferous tubules compared to the Wistar controls. In conclusion, we demonstrated GABAergic system in the seminiferous tubules of control and GAERS rats, in parallel with the previous studies; and there were alterations in this system in GAERS. We suggest that these alterations in absence epilepsy may also affect the gonadal system, resulting in decreased sperm production.

KEY WORDS: GAERS, GABA; Testis; Electron microscopy; Immunohistochemistry.

\section{INTRODUCTION}

Epilepsy is a disease affecting approximately 50 million people worldwide (McKeown \& McNamara, 2001; Engel Jr., 2008; Kuruba et al., 2009). Seizure frequency during puberty in male patients with epilepsy increases and this condition is associated with increased androgen levels (Edwards et al., 1999). It was reported that testosterone and/ or its metabolites affect amygdala seizure thresholds and development of secondary generalization (Mejías-Aponte et al., 2002). It was shown that amygdala kindling seizures in male rats increased testis, epididymis and pituitary gland weights, decreased prostate weight, and increased serum testosterone, estradiol, and prolactin levels (Taubøll et al., 2008). According to Montouris \& Morris 3rd (2005), hypogonadism may trigger epileptic discharges, and prenatal factors related to brain and reproductive system development may play a role in epilepsy and related reproductive disorders. Moreover, previous studies have shown the adverse effects of epileptic seizures on reproductive health (Morrell \& Montouris, 2004). Previous studies have shown that reproductive hormones are affected in epilepsy and GABAergic system has an effect on gonads (Edwards et al.; Verrotti et al., 2011).

GABA is the main inhibitory neurotransmitter in the central nervous system (Du et al., 2013), therefore, alterations of GABA level may result in neuronal diseases. Beside neuronal tissues, GABA is also expressed in non-neuronal tissues such as testis (Akinci \& Schofield, 1999), epididymis (Geigerseder et al., 2003) and vas deferens (Erdö et al., 1983). GABA, as a trophic factor, has an important role in regulator mechanisms including proliferation, differentiation and migration (Houser, 1991; Kleppner \& Tobin, 2001; Sanchez et al., 2017). There is evidence that GABA has a role in the secretion of testosterone (Reddy \& Jian, 2010).

Recent evidence showed that GABAergic components were expressed in spermatogonial stem cells (Du et al.). Geigerseder et al. (2003) reported GABA and

\footnotetext{
${ }^{1}$ Marmara University, School of Medicine, Department of Histology and Embryology, Istanbul, Turkey.

${ }^{2}$ Istanbul Medipol University, School of Medicine, Department of Histology and Embryology, Istanbul, Turkey.

${ }^{3}$ Istanbul Medipol University, Research Institute for Health Sciences and Technologies (SABITA), Istanbul,Turkey.
} 
GABABR, which is a metabotropic receptor, had an important role in spermatogenesis. GABAAR was immunolocalized in Leydig cells (Geigerseder et al., 2004). Glutamic acid decarboxylase (GAD), an enzyme converting glutamate to GABA, is expressed in GABAergic neurons, pancreatic beta cells, and testis (Reetz et al., 1991; Tillakaratne et al., 1992). Liu et al. (2010) observed that GAD67A and GAD67B is expressed mainly in the brain, lung, ovary, testis, and epididymis, and in small amounts in the heart, spleen, skeletal muscle, uterus and corpus epididymis while GAD67C is only expressed the testis.

In the study by Vergnes et al. (1990) researchers realized that $30 \%$ of Wistar rats had synchronous bilateral spike-and-wave discharges (SWDs), and inbred them; then, called this strain as GAERS. In the present study, we aimed to examine the localization of GABA by immunohistochemical and immunocytochemical methods at the light and electron microscopic level in the testis tissue of control Wistar rats and in rats with genetic absence epilepsy (Genetic Absence Epilepsy Rats from Strasbourg [GAERS]), based on the fact that changes in reproductive hormones may cause infertility. Urogenital system is investigated in epilepsy in the literature, however, histopathological examination has not been shown before to enlighten the mechanism. Therefore, this study is important in enlightening the mechanisms of reproductive disorders and a base for developing new therapeutic strategies in male patients with epilepsy. Furthermore, the present study is the first study to show GABA at the light and electron microscopic level in GAERS strain.

\section{MATERIAL AND METHOD}

Animals. Animals were obtained from Marmara University, The Experimental Animal Implementation and Research Center. This study was conducted in strict accordance with the recommendations of the National Institutes of Health's Guide for the Care and Use of Laboratory Animals. The research protocol with animal experimentation was approved by the Marmara University Local Ethical Committee for Experimental Animals (48.2014.mar). All surgery was performed under sodium pentobarbital anesthesia and every effort was made to minimize suffering.

Four-month-old male Wistar rats and GAERS were used in the present study. The animals were housed with free access to water and food in a 12-h light/dark cycle controlled room at $20 \pm 3{ }^{\circ} \mathrm{C}$. Wistar rats and GAERS were divided into two groups for electron microscopy $(\mathrm{n}=5)$ and for light microscopy $(\mathrm{n}=6)$.
Perfusion fixation. After the animals were anesthetized deeply, they were perfused through the aorta $(50 \mathrm{ml} / \mathrm{min})$ with a fixative solution containing $0.5 \%$ paraformaldehyde, $2.5 \%$ glutaraldehyde and $0.1 \%$ picric acid in $0.1 \mathrm{M} \mathrm{HEPES}$ ( $\mathrm{pH}$ 7.4) for electron microscopy, and with $4 \%$ paraformaldehyde in 0.1 M PBS (pH 7.4) for light microscopy. Then, the testis tissues were dissected and left in the same fixative overnight.

Morphological examination. Testis tissues were dehydrated in increasing series of ethanol and then cleared in xylene. After incubation in liquid paraffin overnight at $60^{\circ} \mathrm{C}$, tissues were embedded in paraffin. Five-micronthick sections were obtained and stained with hematoxylene and eosin for general structure, Masson's trichrome for observing connective tissue, and with periodic acid-Schiff reaction for acrosome and basement membrane alterations. Sections were examined under an Olympus BX51 light microscope (Tokyo, Japan) and photographed by Olympus DP72 CCD camera system (Tokyo, Japan). Randomly selected 5 areas were photographed at 100X magnification, and diameter and area of seminiferous tubules were measured by NIH Image Analysis (Image J) program.

TUNEL method. Apoptag Plus Peroxidase in situ Apoptosis Detection Kit (Millipore S7101) was applied according to manufacturer's protocol. Counterstaining was made with Mayer's hematoxyline. Dark brown stained cells were accepted as TUNEL positive cells. The apoptotic index was calculated as the ratio of the seminiferous tubules which have at least 3 TUNEL positive cells to the total number of seminiferous tubules (Hu et al., 2003).

Immunohistochemistry and histological score. After deparaffinization and dehydration of $5-\mu \mathrm{m}$-thick sections, endogenous peroxidase activity was blocked with $3 \%$ hydrogen peroxide. Citrate buffer solution was used for antigen retrieval. Sections were incubated in blocking solution of IHC Detection Kit (Invitrogen Histostain Plus 3rd Gen 85-9673) for 1 hour and then incubated with antiGABA antibody (Sigma A2052) overnight in a humidified chamber at $4{ }^{\circ} \mathrm{C}$. The goat anti-rabbit antibody was used as secondary antibody and streptavidin peroxidase solution was applied according to the manufacturer's protocol. After applying DAB chromogen, counterstaining was made with Mayer's hematoxyline. Negative controls were done by omitting the primary antibody.

Ten seminiferous tubules from each section were examined at X400 magnification for the quantitative analysis of GABA positive cells. The score was calculated as the ratio of the number of immunopositive cells to the 
number of all spermatogenic epithelium of each seminiferous tubule. GABA index was also calculated separately for spermatogonial stem cells, primary spermatocytes, secondary spermatocytes+early spermatids, and mature spermatids.

Transmission electron microscopy (TEM) and immunogold method. After perfusion fixation, testis tissues were dissected and left in the same fixative overnight. Then, tissues were postfixed in $1 \%$ osmium tetroxide for 1 hour. Following dehydration, tissues were placed in epon-propylene oxide mixture (1:1) overnight. The tissues were then blocked in Epon 812, and then polymerized at $60^{\circ} \mathrm{C}$ overnight. Semi-thin sections were obtained by using an ultramicrotome (Leica Ultracut R) and toluidine blue-stained sections were examined under a light microscope to select the area of interest. After trimming the blocks, thin sections were placed onto 200 mesh nickel grids coated with grid coating pen.

Thin sections were incubated in TBST $(0.1 \%$ Triton $\mathrm{X}-100,0.9 \%$ sodium chloride in $0.05 \mathrm{M}$ Tris buffer, $\mathrm{pH}$ 7.6) and then in anti-GABA antibody (Sigma A2052, 1:20000, diluted in TBST pH 7.6) in a humidified chamber at room temperature, overnight. The day after, sections were incubated in TBST pH 7.6 and in TBST pH 8.2. Sections were then incubated for 90 minutes in $10 \mathrm{~nm}$ diameter gold particles attached secondary IgG antibody (Sigma G7402, diluted 1:50 in TBST $\mathrm{pH}$ 8.2) Following washing in TBST pH 7.6 and distilled water, sections were air-dried. Uranyl acetate and lead citrate were used to increase contrast. Negative control experiments were done by omitting the primary antibody. Sections were examined and photographed by using SIS Morada CCD camera attached JEOL 1200 EXII transmission electron microscope.

Statistical Analysis. The data were analyzed with the student's t-test and statistical analysis was made using GraphPad Prism 8 program. The level of statistical significance was considered as $\mathrm{p}<0.05$.

\section{RESULTS}

Morphological examination. The seminiferous tubules of the control group had normal morphology (Fig. 1A). Seminiferous tubules showed every level of the spermatogonial epithelium (spermatogonium, primary spermatocyte, secondary spermatocyte, and spermatid) from basal layer to the lumen and an intense accumulation of spermatozoa in the lumen. Interstitial connective tissue and basal membrane showed normal morphology.
In contrast to the control group, seminiferous tubules of GAERS group were disorganized and the thickness of spermatogonial epithelium was decreased (Fig. 1B). The gap between the cells and irregular localization was remarkable. As a qualitative observation, the tail density of mature spermatozoa in the lumen of seminiferous tubules in GAERS group was less than the control group.

Masson's trichrome staining showed no evidence of fibrosis in both groups (Figs. 1C,D). In both groups, PAS reaction was positive in the acrosome of spermatids at Golgi and cap phases (Figs. 1E, F).

TUNEL staining. Statistical analysis showed that the apoptotic index of GAERS was $0.091 \pm 0.005$, which was significantly higher than the Wistar group $(0.022 \pm 0.004$; p<0.0001) (Figs. 1G, H, and Fig. 2).

Seminiferous tubule area. Randomly selected 10 areas from each section were photographed at $\times 100$ magnification. The area of seminiferous tubules on each image was measured using NIH Image Analysis (Image J) program. The average of seminiferous tubule area was $103542 \pm 8894 \mu \mathrm{m}^{2}$ in Wistar group and $89828 \pm 6645 \mu \mathrm{m}^{2}$ in GAERS group. The difference between the two groups was not statistically significant (Fig. 2).

GABA immunoreactivity and histological score. In both groups, GABA immunopositive cells were observed in different spermatogenic stages of seminiferous tubules, including spermatogonial stem cells, primary spermatocytes, secondary spermatocytes, and early and late spermatids (Fig. 3). Leydig cells also showed positive immunoreactivity in both groups (Fig. 3). No immunoreactivity was observed in the negative control sections of both groups.

Quantitative analysis showed that GABA immunoreactivity was less in GAERS group, compared to the Wistar control group.

Total GABA (+) cell index was significantly decreased in GAERS group $(0.345 \pm 0.015)$ compared to the Wistar control group $(0.449 \pm 0.016)(\mathrm{p}<0.001$; Fig. 4). GABA (+) cell index of spermatogonial stem cells $(0.013 \pm 0.002$ in Wistar group and $0.010 \pm 0.000$ in GAERS group) and primary spermatocytes $(0.038 \pm 0.004$ in Wistar and $0.030 \pm 0.004$ in GAERS group) in GAERS showed a tendency to decrease, however, it was not statistically significant. GABA (+) cell index of secondary spermatocytes+early spermatids was significantly decreased in GAERS group $(0.025 \pm 0.002)$, compared to the Wistar control group $(0.047 \pm 0.009)(\mathrm{p}<0.05$; Fig. 4). 

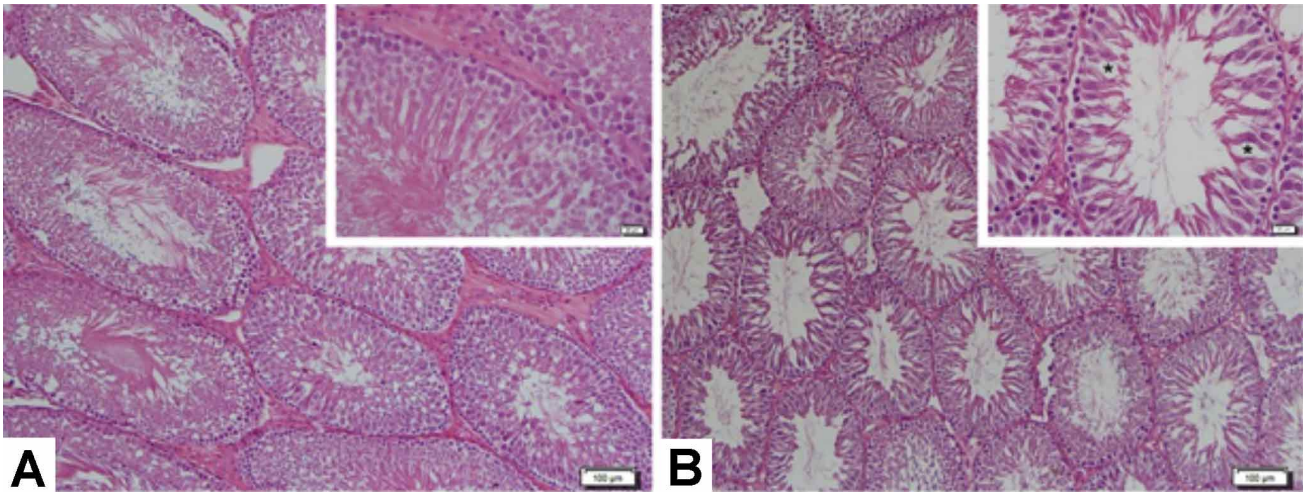

Fig. 1. (A) Normal morphology of seminiferous tubules and spermatogenic
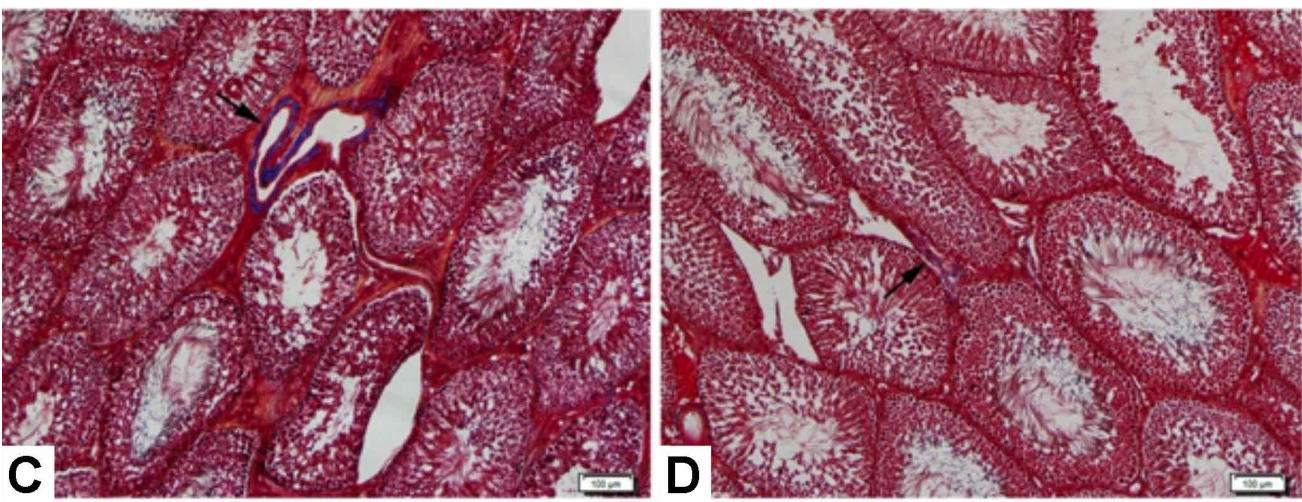
cells in Wistar control group. Hematoxylin and eosin staining. Bar: $100 \mu \mathrm{m}$, inset: 20 $\mu \mathrm{m}$. (B) Disorganization in spermatogenic cells and decrease in mature spermatids in GAERS group. Inset: Gap between germ cells (asterisk). Hematoxylin and eosin staining. Bar: $100 \mu \mathrm{m}$, inset: 20 $\mu \mathrm{m}$. Connective tissue (arrow) in the interstitial area in Wistar (C) and GAERS (D) groups.
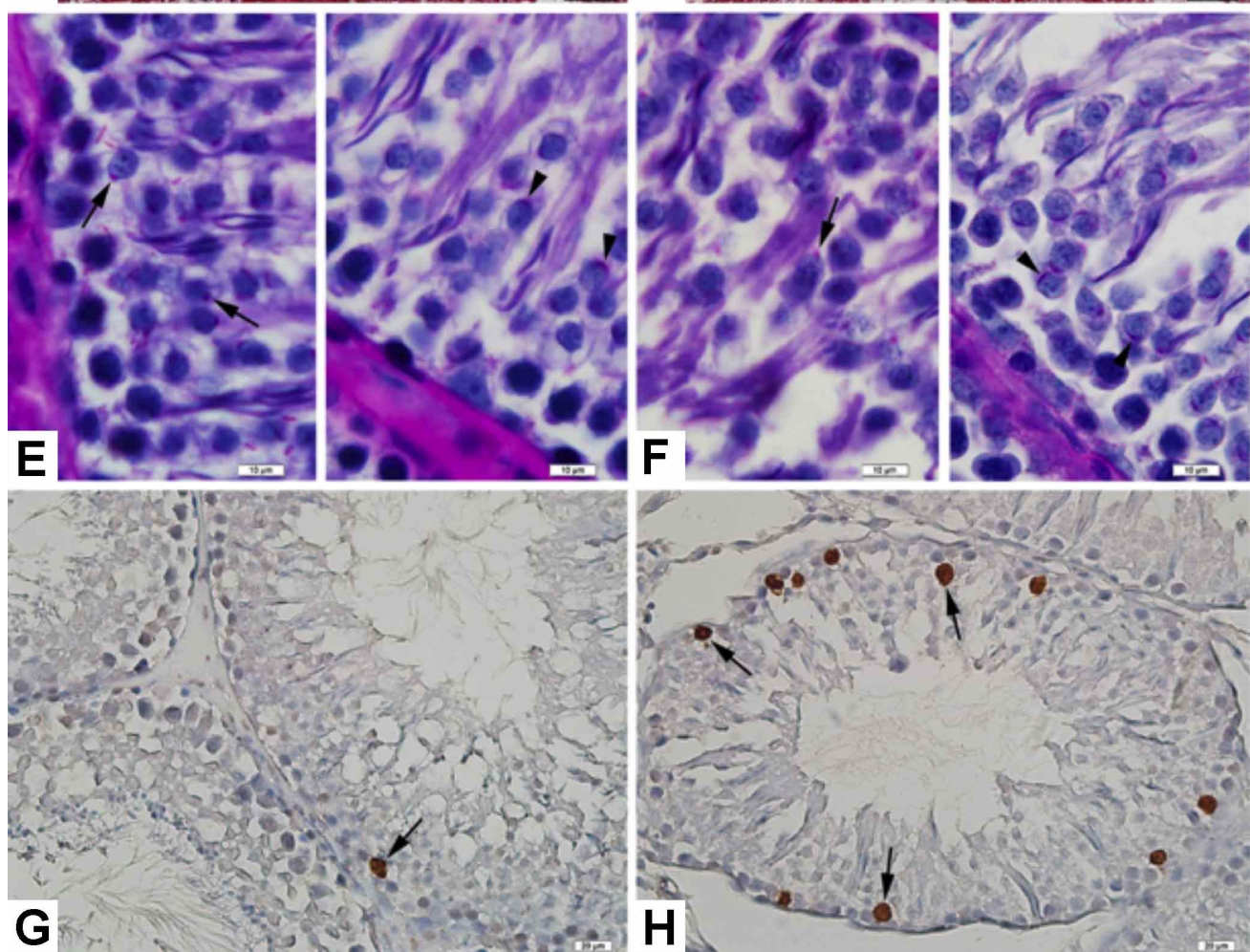

Masson's trichrome staining. Bars: $100 \mu \mathrm{m}$. (E) PAS (+) spermatid acrosomes in Golgi phase (arrow, left) and cap phase (arrowhead, right) in Wistar group. PAS reaction. Bars: $10 \mu \mathrm{m}$. (F) PAS (+) spermatid acrosomes in Golgi phase (arrow, left) and cap phase (arrowhead, right) in GAERS group. PAS reaction. Bars: $10 \mu \mathrm{m}$. (G) TUNEL (+) cell (arrow) in a seminiferous tubule of the control group. Counterstaining: Mayer's hematoxylin. Bar: $20 \mu \mathrm{m}$. (h) Several TUNEL (+) cells (arrows) in a seminiferous tubule of the GAERS group. Counterstaining: Mayer's hematoxylin. Bar: $20 \mu \mathrm{m}$.

No significance was found in GABA $(+)$ cell index for mature spermatids between two groups $(0.352 \pm 0.016$ in Wistar control group and $0.364 \pm 0.086$ in GAERS group).
Immuno-electron microscopy. Acroplaxome, acrosomal vesicle and acrosomal granules of spermatids were distinguished prominently in both groups (Fig. 5). Positive 

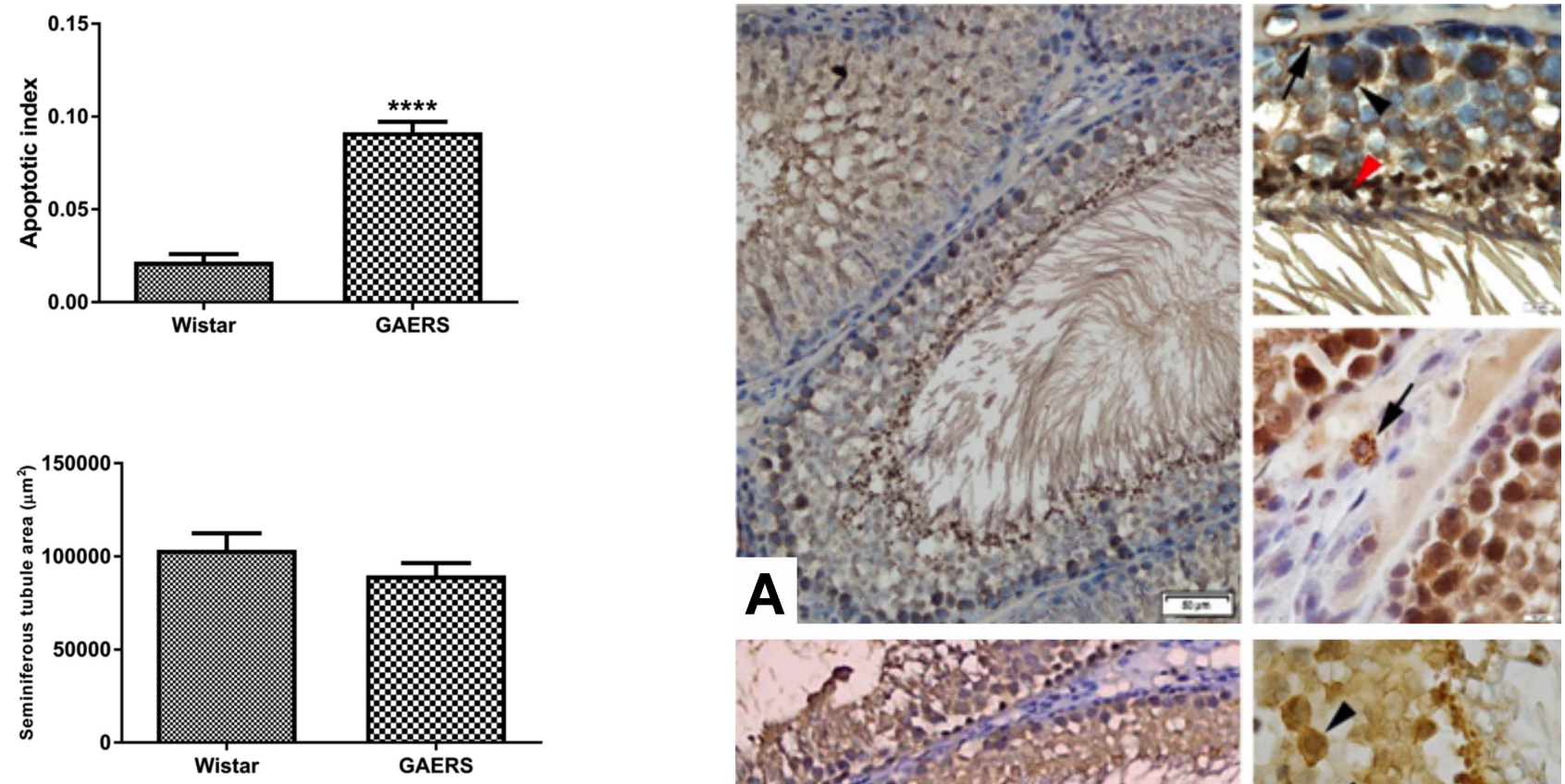

Fig. 2. Comparison of apoptotic cell index and seminiferous tubule area in Wistar control and GAERS groups $(* * * * \mathrm{p}<0.001)$.
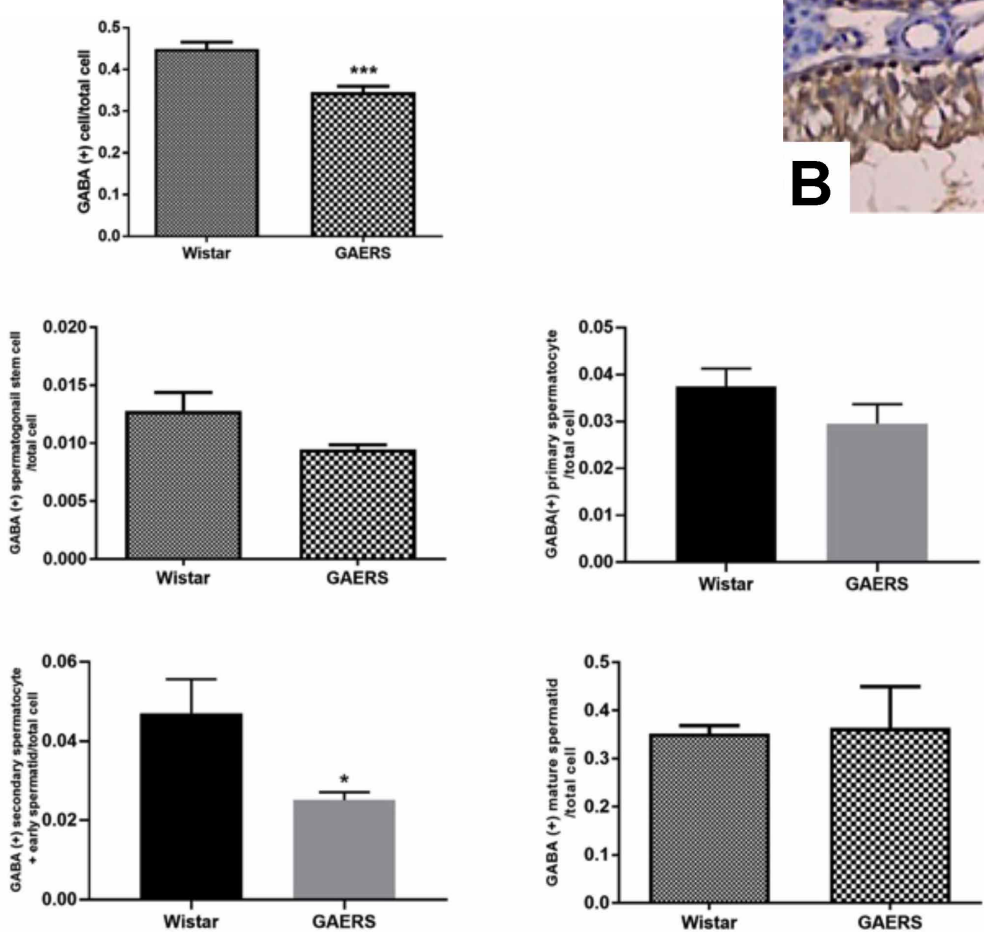

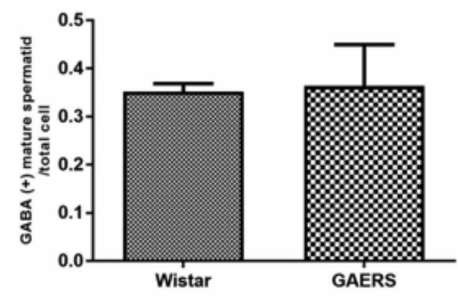

Fig. 3. (A) GABA immunoreactivity in the seminiferous tubules of Wistar control group. Bar: $50 \mu \mathrm{m}$. Upper inset: GABA immunoreactive spermatogonial stem cell (arrow), primary spermatocyte (arrowhead), and mature spermatid (red arrowhead). Lower inset: GABA immunoreactive Leydig cell (arrow). Bars: $10 \mu \mathrm{m}$. Counterstaining: Mayer's hematoxylin. (B) GABA immunoreactivity in the seminiferous tubules of GAERS group. Bar: $50 \mu \mathrm{m}$. Upper inset: GABA immunoreactive spermatogonial stem cell (arrow), primary spermatocyte (arrowhead), and mature spermatid (red arrowhead). Lower inset: GABA immunoreactive Leydig cell (arrow). Bars: $10 \mu \mathrm{m}$. Counterstaining: Mayer's hematoxylin.

Fig. 4. Comparison of GABA $(+)$ cell $(* * * p<0.001)$, spermatogonial stem cell, primary spermatocyte, secondary spermatocyte+early spermatid $(* \mathrm{p}<0.05)$, and mature spermatid cell indices in Wistar control and GAERS groups. 

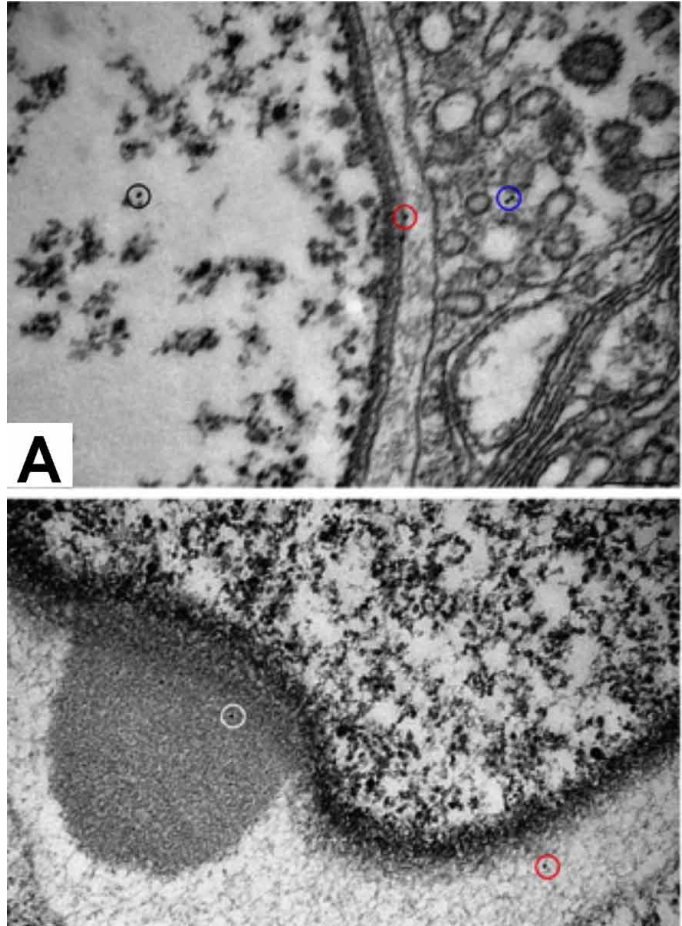

C.
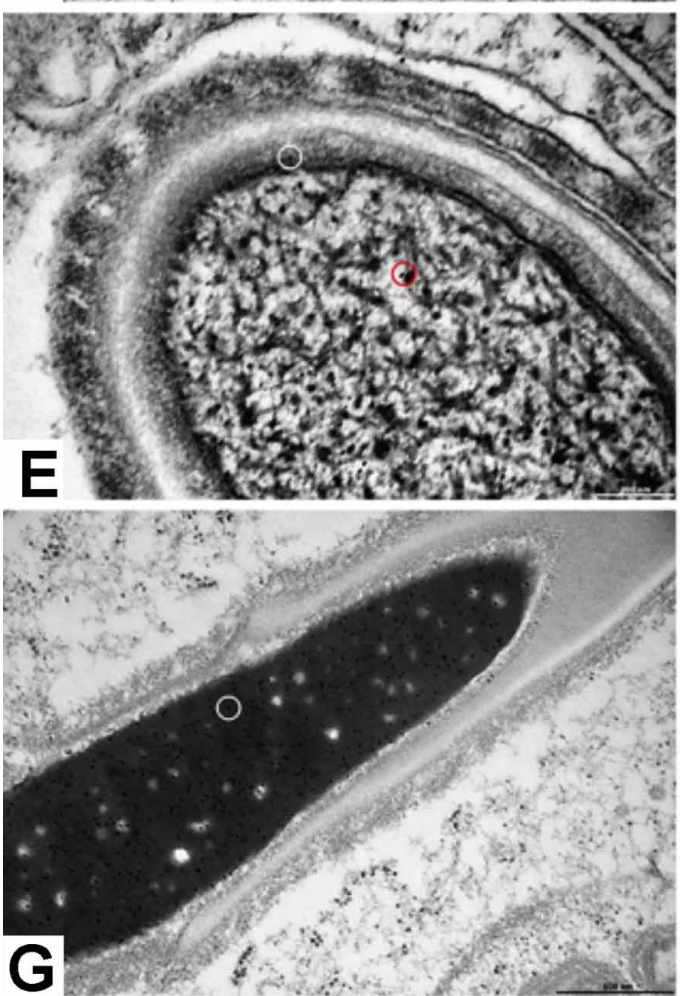
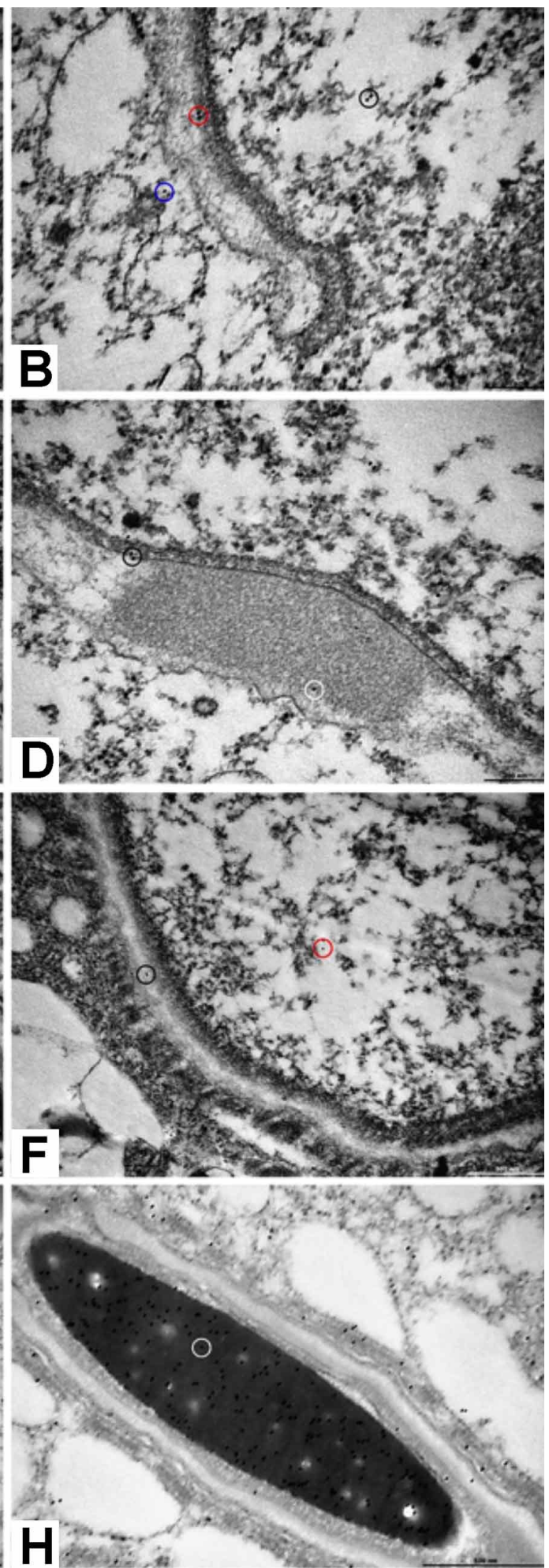

Fig. 5. GABA immunoreactivity the nucleus (black circle), inner acrosomal membrane (red circle), and cytoplasm (blue circle) of cap phase spermatids in Wistar control (A) and GAERS (B) groups. Bars: 200 nm. (C) GABA immunoreactivity in the acrosomal granule (white circle) and acrosomal vesicle (red circle) in the cap phase spermatid of Wistar control group. Bar: $500 \mathrm{~nm}$. (D) $\quad \mathrm{GABA}$ immunoreactivity in the acrosomal granule (white circle) and inner acrosomal membrane (black circle) in the cap phase spermatid of GAERS group. Bar: 200 nm. (E) GABA immunoreactivity in the nucleus (red circle) and acroplaxome (white circle) of a spermatid in the acrosome phase in Wistar control group. Bar: 200 nm. (F) GABA immunoreactivity in the nucleus (red circle) and acrosome vesicle (black circle) of a spermatid in the acrosome phase in GAERS group. Bar: 500 nm. Positive GABA immunoreactivity (circle) in the nucleus of spermatids in maturation phase in Wistar control (G) and GAERS (h) groups. Bars: $500 \mathrm{~nm}$. 


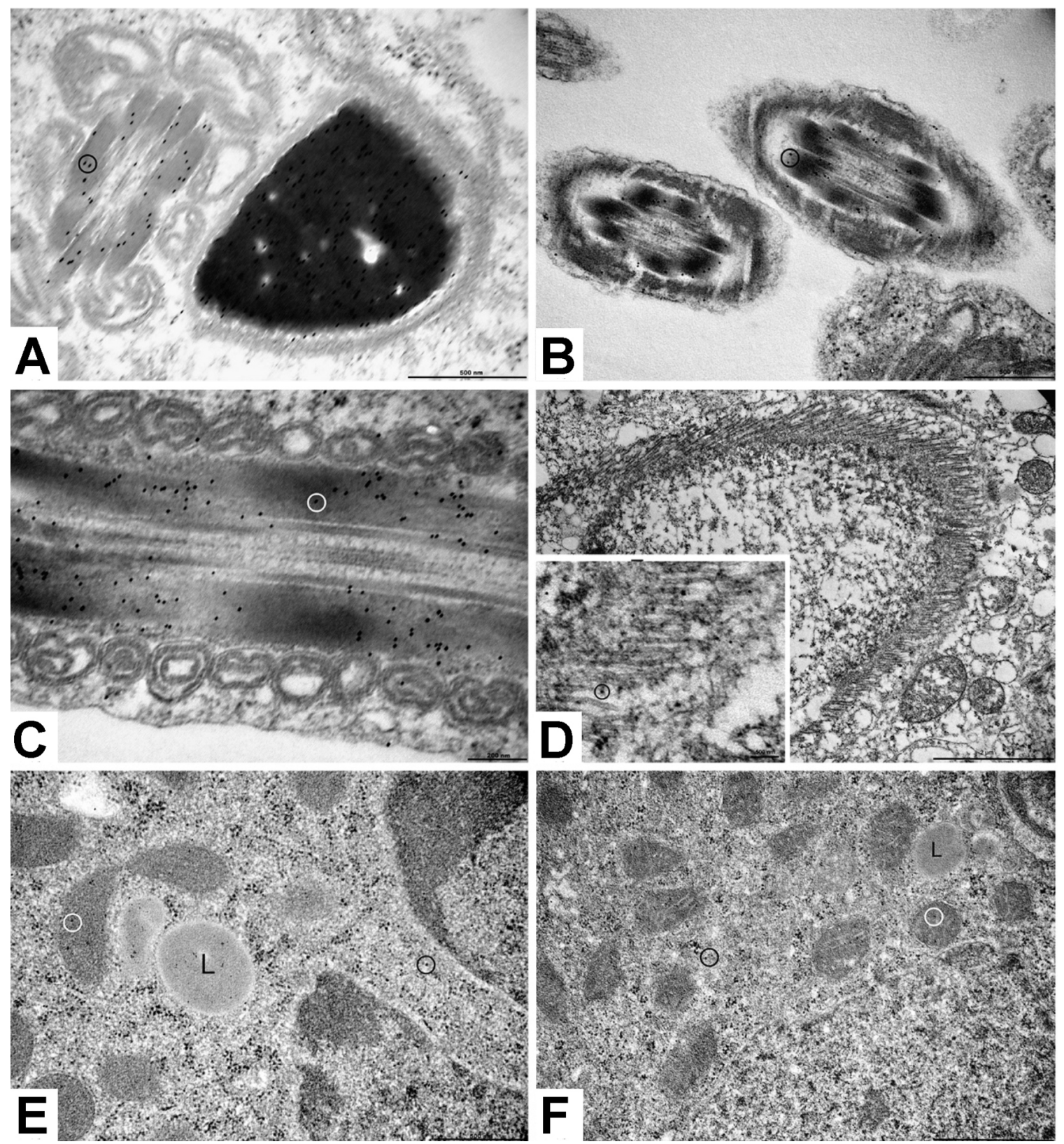

Fig. 6. Positive GABA immunoreactivity (circle) in the outer dense fibers of Wistar control (A) and GAERS (B) groups. Bars: $500 \mathrm{~nm}$. (C) Positive GABA immunoreactivity (circle) in the outer dense fibers in the neck region of mature spermatid in GAERS group. Bar: $200 \mathrm{~nm}$. (D) GABA positivity (circle in the inset) in the manchette microtubules of GAERS group. Bar: $2 \mu \mathrm{m}$. Inset bar: $500 \mathrm{~nm}$. GABA immunoreactivity in the mitochondria (white circle) and cytoplasm (black circle) in the Leydig cell of Wistar control (E) and GAERS (F) groups. L: Lipid droplet. Bar in (E): $500 \mathrm{~nm}$, bar in (F): $1 \mu \mathrm{m}$.

GABA immunoreactivity was observed on the nucleus, inner acrosomal membrane, cytoplasm, acrosome granule, and in acrosome vesicle of cap phase spermatids. Acrosomal phase spermatids showed GABA immunoreactivity on the nucleus, acroplaxome and acrosome vesicle. The nucleus, acroplaxome and acrosome vesicles of maturation phase spermatids showed less GABA density in GAERS group compared to the Wistar control group. GABA immunoreactivity was also positive in outer dense fibers of the tail region in both groups (Fig. 6). Manchette microtubules were also GABA positive. In both groups, mitochondria, nucleus and cytoplasm, except lipid droplets, showed positive GABA immunoreactivity in Leydig cells. No immunoreactivity was seen on negative control sections of both groups. 


\section{DISCUSSION}

In the present study, which investigates testis morphology and GABA immunoreactivity in genetic absence epilepsy rats (GAERS), morphological disorders in seminiferous tubules, decrease in spermatozoa, increase in apoptotic index, and decrease in GABA immunoreactivity in GAERS were observed.

Epileptic seizures and anti-epileptic medications have negative effect on reproductive health (Montouris \& Morris). To our knowledge, there is no study in the literature investigating the relation between absence epilepsy and reproductive system. Therefore, this study is important in that, for the first time in the literature, testis tissue of GAERS was examined by light and electron microscopic methods. Our findings show that reproductive system in absence epilepsy is negatively affected, as in temporal lobe epilepsy and this condition might result in infertility.

GABA has a role in important metabolic activities in testis (Geigerseder et al., 2004; Kanbara et al., 2005). The expression of mRNA for glutamic acid decarboxylase, the enzyme which synthesizes GABA, was reported in germ cells of male rats in 1990 (Persson et al., 1990). The same study reported the presence of GAD mRNA in mouse, guinea pig, pig and monkey testis as well. Fetal Leydig cells of 5-6-dayold rats express GAD protein, and both fetal and adult Leydig cell series have GABAA receptor subunit (Geigerseder et al., 2004). Immunolocalization of GABAa1 protein was observed in Leydig cells (Geigerseder et al., 2003). Another study reported that GABA immunoreactivity was not observed in interstitial cells and peritubular myoid cells but was restricted to the seminiferous tubules (Du et al.). Leydig cells were shown to possess enzymatically active VGAT, GAD65/67 (located in cytoplasm) and GABAA and GABAB receptor subunits (Geigerseder et al., 2003). It was reported that GABA might regulate Leydig cell functions by behaving as auto/ paracrine molecule (Ritta et al., 1991; Geigerseder et al., 2004). In the present study, we showed positive GABA immunoreactivity in Leydig cells in the interstitial area of Wistar control rats and GAERS both in light and electron microscopic observations. In ultrastructural observations, we showed that GABA was localized both in the cytoplasm and nucleus of Leydig cells. Based on these observations, we concluded that GABA synthesis was achieved in the cytoplasm and it was present in the nucleus as a result of transport. Components of GABAergic system is found in the endocrine part of the rodent testis and regulate Leydig cell proliferation by GABA and GABAA receptors (Geigerseder et al., 2004). GABA might be an initial signal for conducting proliferation and differentiation of Leydig cell mesenchymal precursors (Habert et al., 2001; Mendis-Handagama \& Ariyaratne, 2001). Based on the previous studies and our observations, we suggest that GABA in Leydig cells might have a role in the proliferation of these cells.

Spermatogonial stem cells express GAD67, GABAAR receptor subunits, and GAT-1 (Hu et al., 2000; Ma et al., 2000; Oatley et al., 2006; Andäng et al., 2008; Kanbara et al., 2011; Du et al.). GABA signaling, as a proliferation inhibitor, provides protection of spermatogonial stem cell homeostasis (Du et al.). In the present study, we observed at the light microscopic level that spermatogonial stem cells in both adult Wistar control rats and GAERS showed positive GABA immunoreactivity; however, there was no statistical significance in GABA $(+)$ cell index between the groups. Our observations prove that GABAergic system is present in the spermatogonial stem cells in absence epilepsy.

GAD and GABA-like immunoreactivity was observed in the seminiferous tubules of rats and in the neck and flagellum of spermatozoa in humans (Persson et al.). Likewise, we observed at the electron microscopic level that GABA immunoreactivity was present in the neck and tail regions of the spermatozoa in Wistar control rats and GAERS. Our observations suggest that GABA might be a regulatory factor in energy production and sperm motility. Similarly, Persson et al. also suggested that GAD and GABA might be important in spermatogenesis and sperm motility. Further studies concerning sperm motility in patients with absence epilepsy are needed to enlighten this topic.

GABA and GABAB1 receptor were reported to be present in the acrosomal vesicle in the cap phase of spermiogenesis, but absent in the acrosomal granule (Kanbara et al., 2005). Another study demonstrated GABA receptor a1 subunit immunoreactivity in the nucleus and mitochondria of spermatocytes and in the acrosomes of spermatids (Kanbara et al., 2010). Similarly, we also showed at the ultrastructural level that GABA was localized in the nucleus, mitochondria, acrosomal vesicle, and acroplaxome in both Wistar control and GAERS groups. On the contrary to the study by Kanbara et al. (2005) we also observed positive GABA immunoreactivity in the acrosomal granule. According to Kanbara et al. (2005) GABAB1 first decreases and then disappears during maturation; whereas GABAB2 displays manchette formation after being localized in the equatorial region, and then is released to residual cytoplasm during maturation phase. In the present study, manchette formation was shown at the electron microscopic level and GABA was demonstrated to be localized on or near the manchette microtubules. In a previous study, it was reported that Marlin, a GABAB receptor binding protein, might have a role in regulating intracellular trafficking by stabilizing microtubules 
(Vidal et al., 2008). Our findings suggest that reduced GABA in GAERS might have a negative effect on intracellular trafficking, which may affect sperm motility. To our knowledge, there is no study about infertility in absence epilepsy, although infertility was reported in convulsive epilepsy (Halász et al., 2004).

The function of GABA receptor in the acrosome was thought to be related to acrosome reaction (Meizel, 1997; Kanbara et al., 2010). The presence of GABAAR in the sperm of mammalians suggests GABA may be a mediator in acrosome reactions (Roldan et al., 1994; Shi \& Roldan, 1995; Turner \& Meizel, 1995; Wistrom \& Meizel, 1993). GABABR might have an important role in mammalian fertilization process by inducing acrosome reaction (Calogero et al., 1999). GABABR subunits during late cap phase may form functional heterodimer form in the inner acrosomal membrane and GABA may bind to these receptors (Kanbara et al., 2005). In this study, observation of GABA immunoreactivity in the inner acrosomal membrane is in line with these findings. GABA and GABAB 1 immunoreactivity is found in the acrosome (Meizel). We also observed GABA immunoreactivity in the acrosome vesicle, acrosome granule, and acroplaxome. GABA and GABABR subunit immunoreactivity decreases toward the end of sperm maturation and then lost (Kerr \& Ong, 1995; Bettler et al., 1997; Bowery \& Enna, 2000; Vidal et al.). It was suggested that GABA and GABABR might provide morphological changes during transformation of spermatid from round to spindle shape by GABABR signaling pathway (Kerr \& Ong; Bettler et al.; Calogero et al.; Bowery \& Enna; Couve et al., 2000).

In the fractionated testis homogenates, the highest GAD mRNA amount was observed in the spermatocyte and spermatid fractions, compared to the lesser amount in Sertoli cell fractions (Persson et al.). Likewise, in the present study, we observed the most intense GABA immunoreactivity was in the mature spermatids close to the lumen of the seminiferous tubules.

In the present study, we observed less GABA $(+)$ cells in GAERS group compared to the control group. Our qualitative observations showed less flagellum in the seminiferous tubule lumens in GAERS group, and this condition might be due to the less GABA amount in this group. Similarly, higher apoptotic cells in GAERS group may also be related to lesser GABA amount in this strain. This study might be a base for further studies about GABAergic system in absence epilepsy. The findings of the present study suggest GABA alterations in absence epilepsy may result in infertility. Further experimental and clinical studies are needed to enlighten this subject.
ACKNOWLEDGEMENT. This study was supported by Marmara University Research Fund (SAG-C-YLP1009140317).

GÜRGEN, D. G.; ÇILINGIR, Ö. T. \& SIRVANCI, S. Inmunorreactividad del ácido gamma-amino butírico en el tejido testicular de ratas Wistar con epilepsia de ausencia genética. Int. J. Morphol., 39(6):1709-1718, 2021.

RESUMEN: Los estudios han demostrado los efectos adversos de las convulsiones epilépticas sobre la salud reproductiva. El objetivo del presente estudio fue investigar los cambios morfológicos, la apoptosis y la localización de GABA en el tejido testicular de ratas con epilepsia de ausencia genética. Se procesaron tejidos testiculares de ratas GAERS y Wistar para inclusión en parafina y microscopía electrónica. Las secciones se tiñeron con hematoxilina y eosina, tricrómico de Masson y reacción de ácido peryódico de Schiff. Se aplicó inmunohistoquímica de GABA para determinar las alteraciones en los niveles de GABA. Se observó inmunorreactividad de GABA en los túbulos seminíferos y las áreas intersticiales de las ratas GAERS y Wistar. Se encontró que la inmunorreactividad de GABA estaba disminuida en GAERS en comparación con el grupo Wistar. Las observaciones microscópicas electrónicas mostraron que GABA estaba presente en los microtúbulos, la cola y el cuello del espermatozoide en diferentes fases de la espermiogénesis. Las observaciones cualitativas revelaron que los tejidos testiculares de GAERS mostraron una reducción de los espermatozoides en los túbulos seminíferos en comparación con los controles Wistar. En conclusión, demostramos el sistema GABAérgico en los túbulos seminíferos de ratas control y GAERS, en paralelo con estudios previos; y además se observaron alteraciones en este sistema en GAERS. Sugerimos que estas alteraciones en epilepisa de ausencia genética también pueden afectar el sistema gonadal, resultando en una disminución de la producción de semen.

PALABRAS CLAVE: GAERS, GABA; Testículo Microscopio de electrones; Inmunohistoquímica.

\section{REFERENCES}

Akinci, M. K. \& Schofield, P. R. Widespread expression of GABA(A) receptor subunits in peripheral tissues. Neurosci. Res., 35(2):145-53, 1999

Andäng, M.; Hjerling-Leffler, J.; Moliner, A.; Lundgren, T. K.; Castelo-Branco, G.; Nanou, E.; Pozas, E.; Bryja, V.; Halliez, S.; Nishimaru, H.; et al. Histone $\mathrm{H} 2 \mathrm{AX}$-dependent GABA(A) receptor regulation of stem cell proliferation. Nature, 451(7177):460-4, 2008.

Bettler, B.; Kaupmann, K. \& Bowery, N. GABAB receptors?: drugs meet clones. Curr. Opin. Neurobiol., 8(3):345-50, 1997.

Bowery, N. G. \& Enna, S. J. Gamma-aminobutyric acid(B) receptors: first of the functional metabotropic heterodimers. J. Pharmacol. Exp. Ther., 292(1):2-7, 2000

Calogero, A. E.; Burrello, N.; Ferrara, E.; Hall, J.; Fishel, S. \& D’Agata, R. Gamma-aminobutyric acid (GABA) A and B receptors mediate the stimulatory effects of GABA on the human sperm acrosome reaction: interaction with progesterone. Fertil. Steril., 71(5):930-6, 1999.

Couve, A.; Moss, S. J. \& Pangalos, M. N. GABAB receptors: a new paradigm in G protein signaling. Mol. Cell. Neurosci., 16(4):296-312, 2000. 
Du, Y.; Du, Z.; Zheng, H.; Wang, D.; Li, S.; Yan, Y. \& Li, Y. GABA exists as a negative regulator of cell proliferation in spermatogonial stem cells. Cell. Mol. Biol. Lett., 18(2):149-62, 2013.

Edwards, H. E.; Burnham, W. M. I. \& MacLusky, N. J. Testosterone and its metabolites affect afterdischarge thresholds and the development of amygdala kindled seizures. Brain Res., 838(1-2):151-7, 1999.

Engel Jr., J. Intractable epilepsy: definition and neurobiology. Epilepsia, 42 Suppl. 6:3, 2008.

Erdö, S. L.; Német, L. \& Szporny, L. The occurrence of GABA in vas deferens, prostate, epididymis, seminal vesicle and testicle of the rat. Acta Biol. Hung., 34(4):435-7, 1983.

Geigerseder, C.; Doepner, R. F. G.; Thalhammer, A.; Krieger, A. \& Mayerhofer, A. Stimulation of TM3 Leydig cell proliferation via GABA(A) receptors: a new role for testicular GABA. Reprod. Biol. Endocrinol., 2:13, 2004.

Geigerseder, C.; Doepner, R.; Thalhammer, A.; Frungieri, M. B.; Gamel-Didelon, K.; Calandra, R. S.; Köhn, F. M. \& Mayerhofer, A. Evidence for a GABAergic system in rodent and human testis: local GABA production and GABA receptors. Neuroendocrinology, 77(5):314-23, 2003.

Habert, R.; Lejeune, H. \& Saez, J. M. Origin, differentiation and regulation of fetal and adult Leydig cells. Mol. Cell. Endocrinol., 179(1-2):47-74, 2001.

Halász, P.; Janszky, J.; Rásonyi, G. Y.; Barcs, G.; Szucs, A.; Holló, A.; Kelemen, A.; Clemens, Z. \& Csepella, Z. Postoperative interictal spikes during sleep contralateral to the operated side is associated with unfavourable surgical outcome in patients with preoperative bitemporal spikes. Seizure, 13(7):4606,2004

Houser, C. R. GABA neurons in seizure disorders: a review of immunocytochemical studies. Neurochem. Res., 16(3):295-308, 1991.

Hu, J. H.; He, X. B. \& Yan, Y. C. Identification of gamma-aminobutyric acid transporter (GAT1) on the rat sperm. Cell Res., 10(1):51-8, 2000.

Hu, J. H.; Jiang, J.; Ma, Y. H.; Yang, N.; Zhang, M. H.; Wu, M.; Fei, J. \& Guo, L. H. Enhancement of germ cell apoptosis induced by ethanol in transgenic mice overexpressing Fas Ligand. Cell Res., 13(5):361-7, 2003.

Kanbara, K.; Mori, Y.; Kubota, T.; Watanabe, M.; Yanagawa, Y. \& Otsuki, Y. Expression of the GABAA receptor/chloride channel in murine spermatogenic cells. Histol. Histopathol., 26(1):95-106, 2011.

Kanbara, K.; Okamoto, K.; Nomura, S.; Kaneko, T.; Shigemoto, R.; Azuma, H.; Katsuoka, Y. \& Watanabe, M. Cellular localization of GABA and GABAB receptor subunit proteins during spermiogenesis in rat testis. $J$. Androl., 26(4):485-93, 2005.

Kanbara, K.; Okamoto, K.; Nomura, S.; Kaneko, T.; Watanabe, M. \& Otsuki, Y. The cellular expression of GABA(A) receptor alpha1 subunit during spermatogenesis in the mouse testis. Histol. Histopathol., 25(10):1229-38, 2010.

Kerr, D. I. \& Ong, J. GABAB receptors. Pharmacol. Ther., 67(2):187-246, 1995.

Kleppner, S. R. \& Tobin, A. J. GABA signalling: therapeutic targets for epilepsy, Parkinson's disease and Huntington's disease. Expert Opin. Ther. Targets, 5(2):219-39, 2001

Kuruba, R.; Hattiangady, B. \& Shetty, A. K. Hippocampal neurogenesis and neural stem cells in temporal lobe epilepsy. Epilepsy Behav., 14(Suppl. 1):6573, 2009.

Liu, H.; Zhang, Y.; Li, S.; Yan, Y. \& Li, Y. Dynamic regulation of glutamate decarboxylase 67 gene expression by alternative promoters and splicing during rat testis maturation. Mol. Biol. Rep., 37:3111-9, 2010.

Ma, Y. H.; Hu, J. H.; Zhou, X. G.; Mei, Z. T.; Fei, J. \& Guo, L. H. Gammaaminobutyric acid transporter (GAT1) overexpression in mouse affects the testicular morphology. Cell Res., 10(1):59-69, 2000.

McKeown, M. J. \& McNamara, J. O. When do epileptic seizures really begin? Neuron, 30(1):1-3, 2001.

Meizel, S. Amino acid neurotransmitter receptor/chloride channels of mammalian sperm and the acrosome reaction. Biol. Reprod., 56(3):56974, 1997.

Mejías-Aponte, C. A.; Jiménez-Rivera, C. A. \& Segarra, A. C. Sex differences in models of temporal lobe epilepsy: role of testosterone. Brain Res., 944(12):210-8, 2002.

Mendis-Handagama, S. M. \& Ariyaratne, H. B. Differentiation of the adult Leydig cell population in the postnatal testis. Biol. Reprod., 65(3):660-71, 2001.

Montouris, G. \& Morris 3rd, G. L. Reproductive and sexual dysfunction in men with epilepsy. Epilepsy Behav., 7 Suppl. 2:S7-14, 2005.
Morrell, M. J. \& Montouris, G. D. Reproductive disturbances in patients with epilepsy. Cleve. Clin. J. Med., 71 Suppl. 2:S19-24, 2004.

Oatley, J. M.; Avarbock, M. R.; Telaranta, A. I.; Fearon, D. T. \& Brinster, R. L. Identifying genes important for spermatogonial stem cell self-renewal and survival. Proc. Natl. Acad. Sci. U. S. A., 103(25):9524-9, 2006.

Persson, H.; Pelto-Huikko, M.; Metsis, M.; Söder, O.; Brene, S.; Skog, S.; Hökfelt, T. \& Ritzén, E. M. Expression of the neurotransmitter-synthesizing enzyme glutamic acid decarboxylase in male germ cells. Mol. Cell. Biol., 10(9):4701-11, 1990.

Reddy, D. S. \& Jian, K. The testosterone-derived neurosteroid androstanediol is a positive allosteric modulator of GABAA receptors. J. Pharmacol. Exp. Ther., 334(3):1031-41, 2010.

Reetz, A.; Solimena, M.; Matteoli, M.; Folli, F.; Takei, K. \& De Camilli, P. GABA and pancreatic beta-cells: colocalization of glutamic acid decarboxylase (GAD) and GABA with synaptic-like microvesicles suggests their role in GABA storage and secretion. EMBO J., 10(5):1275-84, 1991.

Ritta, M. N.; Campos, M. B. \& Calandra, R. S. Coexistence of gammaaminobutyric acid type $\mathrm{A}$ and type $\mathrm{B}$ receptors in testicular interstitial cells. J. Neurochem., 56(4):1236-40, 1991.

Roldan, E. R.; Murase, T. \& Shi, Q. X. Exocytosis in spermatozoa in response to progesterone and zona pellucida. Science, 266(5190):1578-81, 1994.

Sanchez, T.; Seidler, E. A.; Gardner, D. K.; Needleman, D. \& Sakkas, D. Will noninvasive methods surpass invasive for assessing gametes and embryos? Fertil. Steril., 108(5):730-7, 2017.

Shi, Q. X. \& Roldan, E. R. Evidence that a GABAA-like receptor is involved in progesterone-induced acrosomal exocytosis in mouse spermatozoa. Biol. Reprod., 52(2):373-81, 1995.

Taubøll, E.; Røste, L. S.; Svalheim, S. \& Gjerstad, L. Disorders of reproduction in epilepsy--what can we learn from animal studies? Seizure, 17(2):120-6, 2008.

Tillakaratne, N. J.; Erlander, M. G.; Collard, M. W.; Greif, K. F. \& Tobin, A. J. Glutamate decarboxylases in nonneural cells of rat testis and oviduct: differential expression of GAD65 and GAD67. J. Neurochem., 58(2):61827, 1992.

Turner, K. O. \& Meizel, S. Progesterone-mediated efflux of cytosolic chloride during the human sperm acrosome reaction. Biochem. Biophys. Res. Commun., 213(3):774-80, 1995.

Vergnes, M.; Marescaux, C. \& Depaulis, A. Mapping of spontaneous spike and wave discharges in Wistar rats with genetic generalized non-convulsive epilepsy. Brain Res., 523(1):87-91, 1990.

Verrotti, A.; Loiacono, G.; Laus, M.; Coppola, G.; Chiarelli, F. \& Tiboni, G. M. Hormonal and reproductive disturbances in epileptic male patients: emerging issues. Reprod. Toxicol., 31(4):519-27, 2011.

Vidal, R. L.; Ramírez, A.; Castro, M.; Concha, I. I. \& Couve, A. Marlin-1 is expressed in testis and associates to the cytoskeleton and GABAB receptors. J. Cell. Biochem., 103(3):886-95, 2008.

Wistrom, C. A. \& Meizel, S. Evidence suggesting involvement of a unique human sperm steroid receptor/Cl- channel complex in the progesteroneinitiated acrosome reaction. Dev. Biol., 159(2):679-90, 1993.

\section{Corresponding author: \\ Duygu Gürsoy Gürgen \\ Department of Histology and Embryology \\ Istanbul Medipol University Medical Faculty \\ Kavacık-Istanbul \\ TURKEY}

\section{E-mail: dgursoy@medipol.edu.tr}

Received: 06-06-2021

Accepted: 10-08-2021 